\title{
Regulation of fat mobilization in adipose tissue of dairy cows in the period around parturition
}

\section{S. H. M. Metz ${ }^{1}$ and S. G. van den Bergh}

Laboratory of Veterinary Biochemistry, State University of Utrecht, Biltstraat 172, Utrecht, the Netherlands

Accepted: 1 June 1977

Key words: dairy cows, adipose tissue, lipolysis, re-esterification, noradrenalin, glucose, parturition

\section{Summary}

Fat mobilization was studied in biopsy samples of subcutaneous adipose tissue obtained from dairy cows in late pregnancy and in early lactation.

During the whole period around parturition noradrenalin stimulates the release of free fatty acids (FFA) and glycerol from adipose tissue by increasing the rate of lipolysis.

The rates of release of FFA and glycerol from adipose tissue samples of cows in early lactation are higher than those from tissue samples of the same animals before parturition. The increased fat mobilization after parturition is caused both by an increased rate of lipolysis and by an almost complete disappearance of the re-esterification of fatty acids in the adipose tissue. The increased release of FFA from the adipose tissue after parturition is paralleled by an increased concentration of FFA in the blood.

Glucose normally inhibits fat mobilization by stimulating the re-esterification of fatty acids, but this effect is not observed in the first weeks after parturition. Addition of insulin does not influence the effects of glucose on fat mobilization.

The over-all regulation of fat mobilization in the adipose tissue of dairy cows in the period around parturition is discussed.

\section{Introduction}

The concentration of long-chain free (non-esterified) fatty acids (FFA) in the blood of dairy cows is increased during the first weeks after calving, whereas the glucose concentration is decreased as compared with the normal level before parturition (Radloff et al., 1966; Schultz, 1968; Mulder, 1971a, 1971b). The turnover time of

1 Present address: Institute for Animal Feeding and Nutrition Research, P.O. Box 160, Lelystad, the Netherlands. 


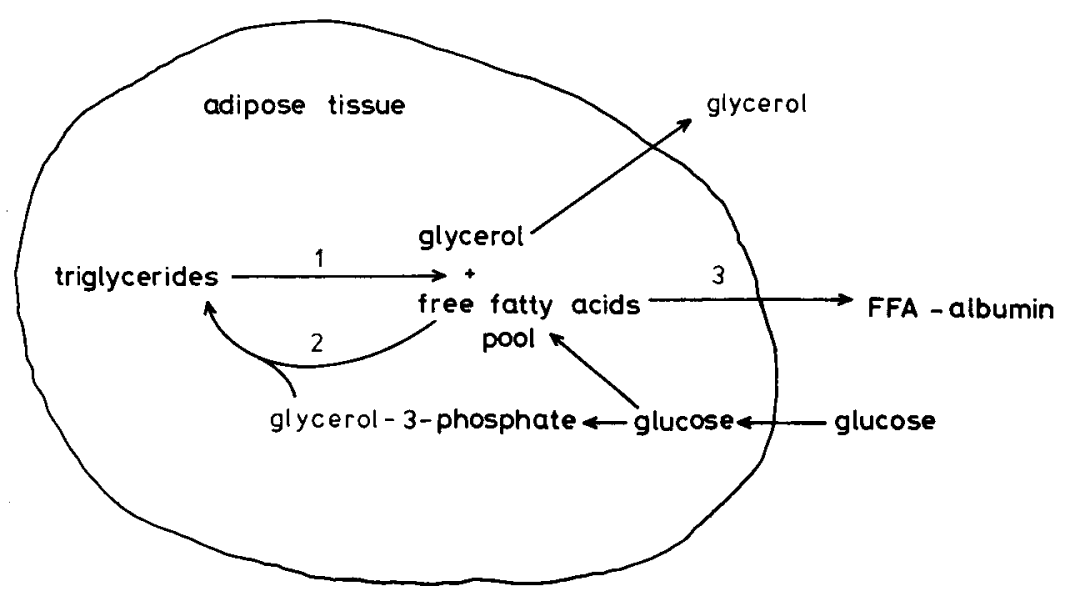

Fig. 1. Lipolysis (reaction 1), re-esterification (reaction 2) and FFA-release (reaction 3) in adipose tissue in relation to the presence of glucose and albumin.

the FFA in the blood remains almost unchanged (Jackson et al., 1968), indicating that the rate of release of fatty acids into the blood stream as well as the rate of uptake of fatty acids from the blood stream must be increased.

The FFA in the blood originate from the adipose tissue in which the fat reserves of the animal are stored as triglycerides (triacylglycerols). These triglycerides are hydrolysed by a hormone-sensitive lipase to glycerol and FFA in a process called lipolysis (Fig. 1, reaction 1). Since the enzyme glycerol kinase is absent from bovine adipose tissue (Metz, 1973), the glycerol cannot be metabolized and must be released into the circulation. Therefore, glycerol release from the adipose tissue is a true measure of lipolysis. The small pool of tissue-associated free fatty acids (TAFA) is either re-esterified to form triglycerides (Fig. 1, reaction 2) or is released into the blood, where it is bound to serum albumin (Fig. 1, reaction 3). The release of FFA from the adipose tissue is called fat mobilization. The term 'fatty acid production' is used to indicate the difference between lipolysis and re-esterification; it equals the sum of the FFA release and the increase of the TAFA pool.

From the foregoing it may be concluded that the rate of release of FFA from the adipose tissue of dairy cows is increased in the first weeks after calving. It was the purpose of the present investigation to find out whether alterations in lipolysis or in re-esterification are responsible for this increased mobilization of fat. The results presented in this paper show that the increased fat mobilization after parturition is caused both by an increased rate of lipolysis and by an almost complete absence of re-esterification in the adipose tissue during that period. It was found that glucose, which normally inhibits fat mobilization by stimulating the re-esterification process, has no such effect in adipose tissue from cows in early lactation. 


\section{Methods and materials}

\section{Animals and management}

Our studies were performed with dairy cows of the Dutch-Friesian and MRY breeds in late pregnancy or early lactation. The animals were fed silage or hay and 6-8 $\mathrm{kg}$ of concentrates daily, so that the need for protein was satisfied both before and after parturition whereas the supply of energy was abundant before parturition and provided for $70-90 \%$ of the need thereafter.

\section{Technique of sampling of blood and adipose tissue}

Samples of blood and subcutaneous adipose tissue were taken from the cows at regular intervals from about a month before until a month after parturition. Blood from the vena jugularis was collected in cooled glass tubes $1-2 \mathrm{~h}$ after the morning feeding of the animals. The samples were kept at $0{ }^{\circ} \mathrm{C}$ and rapidly transported to the laboratory. Heparin plasma was prepared immediately and stored at $-18^{\circ} \mathrm{C}$ until further analysis.

Adipose tissue samples were taken from the flank region (fossa paralumbalis), 2-4 $\mathrm{h}$ after feeding. Using the method of paravertebral anaesthesia, it was possible to anaesthetize the flank region without directly contaminating the adipose tissue with the anaesthetic (prilocain). An incision of $10-15 \mathrm{~cm}$ length was made in the skin and 15-25 g of adipose tissue were removed. The wound was sutured afterwards.

\section{Handling of the adipose tissue in vitro}

Immediately after removal from the animal the tissue samples were put in a physiological saline solution of $37^{\circ} \mathrm{C}$ and rapidly transported to the laboratory. There they were freed as much as possible from vascular and connective tissue, cut into pieces of $10-30 \mathrm{mg}$ and preincubated for $15 \mathrm{~min}$ in a Krebs-Ringer bicarbonate buffer ( $\mathrm{pH} 7.35$ ) with $5 \%$ bovine serum albumin. For the experimental incubations the tissue pieces were filtered, blotted, and added in portions of $300-500 \mathrm{mg}$ to polythene vials with screw caps containing $10 \mathrm{ml}$ of fresh buffer of the same composition as that used for the preincubation. All incubations were carried out in a shaking water bath (100 oscillations/min) at $37^{\circ} \mathrm{C}$. After a 25 -min incubation, a sample of the medium was taken for zero-time analyses and, if necessary, hormones and glucose were added as aqueous solutions. The incubations were stopped 120 minutes later by putting the vials in ice. The tussue pieces were filtered from the media and the latter were stored at $-18^{\circ} \mathrm{C}$ until further analysis. In some experiments, the tissue pieces were thoroughly rinsed with a physiological saline solution, blotted, and homogenized in $10 \mathrm{ml}$ of Dole's extraction mixture (Dole, 1956) in order to determine the amount of TAFA. The procedures for determining the amount of TAFA have been described previously (Metz et al., 1973).

Quantitative determination of FFA in blood samples and in the incubation media was carried out by the titration method of Dole (1956). Glycerol was measured according to Eggstein \& Kreutz (1966) with a test set of Boehringer, Mannheim. 


\section{Chemicals}

Bovine serum albumin (Pentex, Fraction V, fatty acid-poor) was obtained from Fluka; crystalline bovine insulin and glucose were from $\mathrm{BDH}$ Chemicals and noradrenalin was from Sigma.

\section{Results}

Effect of noradrenalin on lipolysis in bovine and in rat adipose tissue

Lipolysis in biopsy samples of bovine subcutaneous adipose tissue is greatly stimulated by noradrenalin at all stages of pregnancy and lactation of the donor animal. The shape of the dose-effect curve is similar to that observed with rat adipose tissue (Fig. 2), although lipolysis in the latter tissue tends to be more sensitive to noradrenalin. In the bovine tissue a maximal stimulation is brought about by approx. $50 \mu M$ noradrenalin.

\section{Fat mobilization in the period around parturition}

The release of FFA and glycerol from adipose tissue samples of cows in late pregnancy and in early lactation is shown in Fig. 3 and 4. The samples were taken from

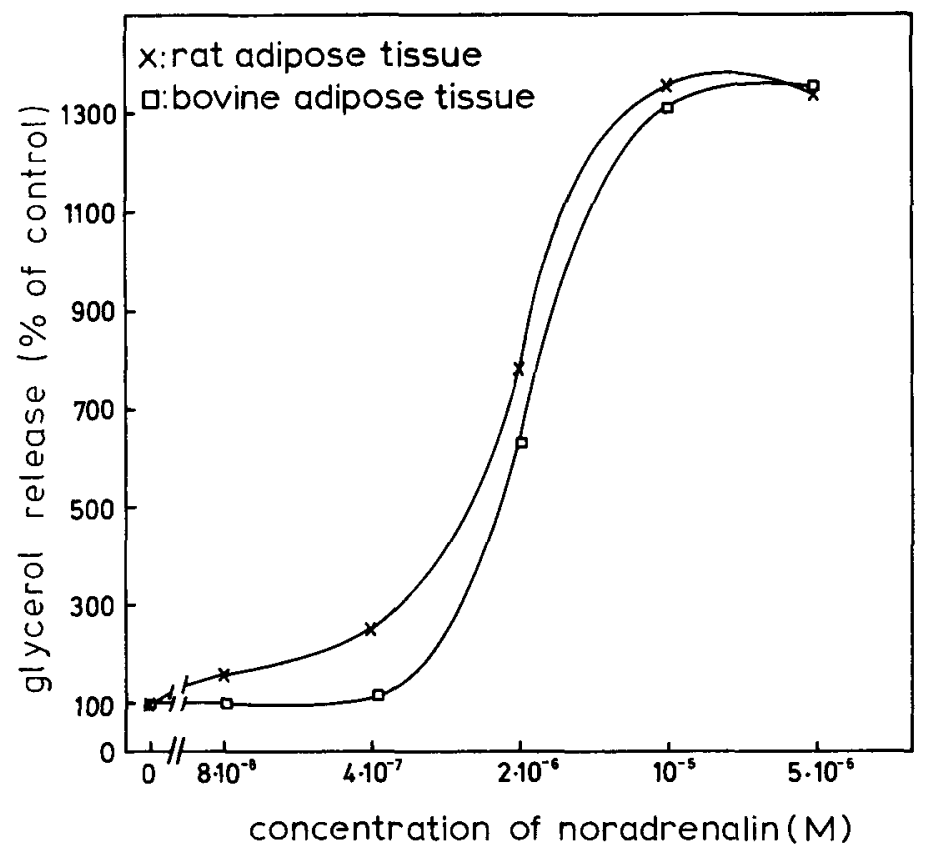

Fig. 2. The effect of noradrenalin on lipolysis in bovine subcutaneous adipose tissue $(\square)$ and in the epididymal fat pad of the rat $(X)$. The adipose tissue was taken from a cow in late pregnancy (17 days before parturition). Fat pads were removed from three adult male rats and treated exactly like the bovine adipose tissue samples. Each point represents the average of triplicate incubations. 


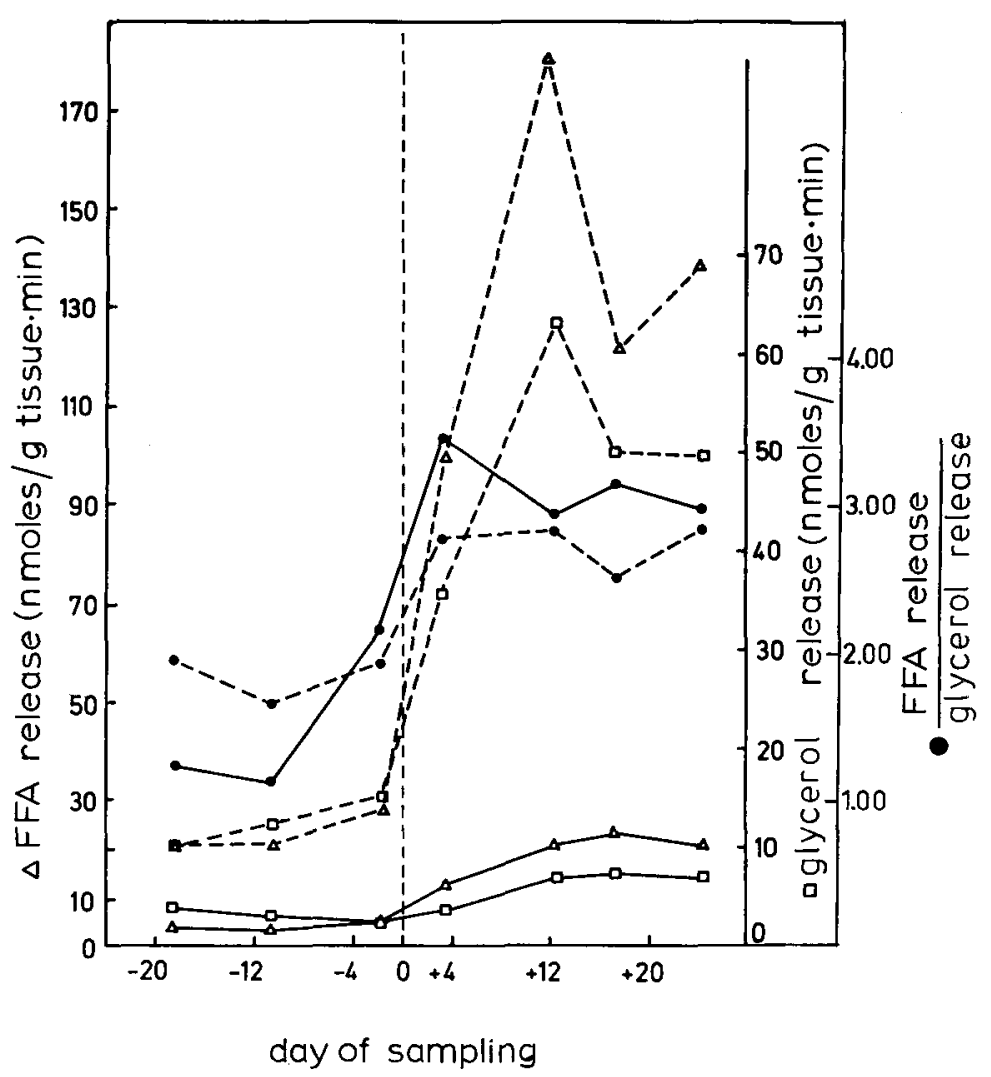

Fig. 3. The release of FFA $(\triangle)$ and glycerol $(\square)$ and the ratio between FFA and glycerol release ( ) from adipose tissue of a cow in the period around parturition. Each point represents the average of quadruplicate incubations. $-\ldots=$ without noradrenalin; - . - = with noradrenalin $\left(2.5 \times 10^{-5} M\right)$.

eight cows; on each cow 3-7 biopsies were performed. Fig. 3 shows the data of one animal; in Fig. 4 the results obtained with all animals are presented.

The rate of release of FFA and glycerol from the adipose tissue is much higher after parturition of the donor animal than before it. This is true for the basal processes (in the absence of noradrenalin) as well as for the noradrenalin stimulated release of FFA and glycerol.

The stimulatory effect of noradrenalin is increased after parturition. Moreover, after parturition the release of FFA is increased more than that of glycerol, resulting in an increased ratio of FFA release over glycerol release. In the absence of noradrenalin this ratio increases from about 1 before parturition to above 3 thereafter. In the presence of noradrenalin the ratio is about 2 before parturition and it increases to about 2.8 after parturition.

The increased FFA release from adipose tissue samples in vitro, observed after 


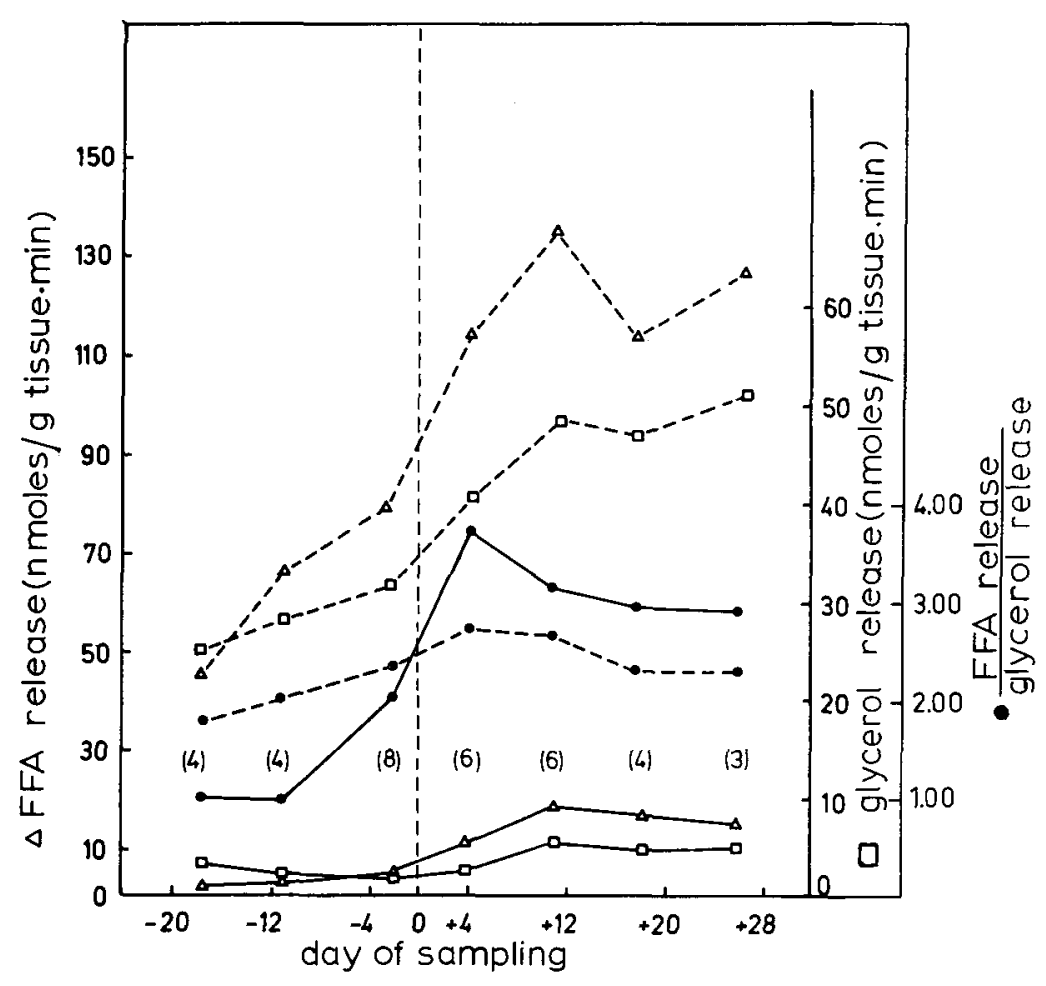

Fig. 4. The release of FFA $(\triangle)$ and glycerol $(\square)$ and the ratio between FFA and glycerol release () from adipose tissue of 8 cows in the period around parturition. From each cow tissue samples were taken both before and after parturition. The experimental period is divided in 7 phases: $28-15,14-8$ and 7-1 days before parturition and 1-7, 8-14, 15-21 and 22-28 days after parturition. The results of all experiments within each phase were combined and the averages are shown in the figure. The number of experiments within each phase is given within parentheses in the figure. Each experiment included triplicate or quadruplicate incubations. $\underline{-}=$ without noradrenalin; $\ldots .-.=$ with $2.5 \times 10^{-5} M$ noradrenalin.

parturition, coincides with a large increase in the concentration of FFA in the blood plasma of the donor animals in vivo (Fig. 5).

\section{Effects of glucose on fat mobilization}

Concentrations of glucose which normally occur in plasma $(3.5 \mathrm{mM})$ inhibit the basal release of FFA from adipose tissue in vitro. This inhibitory effect of glucose is not observed, however, with adipose tissue samples obtained from cows in early lactation. As shown in Table 1, the effects of glucose on the production of FFA are almost identical to those on the release of FFA.

In the presence of noradrenalin (Table 2) the situation is more complicated. Again, no inhibition of FFA production by glucose is observed in early lactation. 


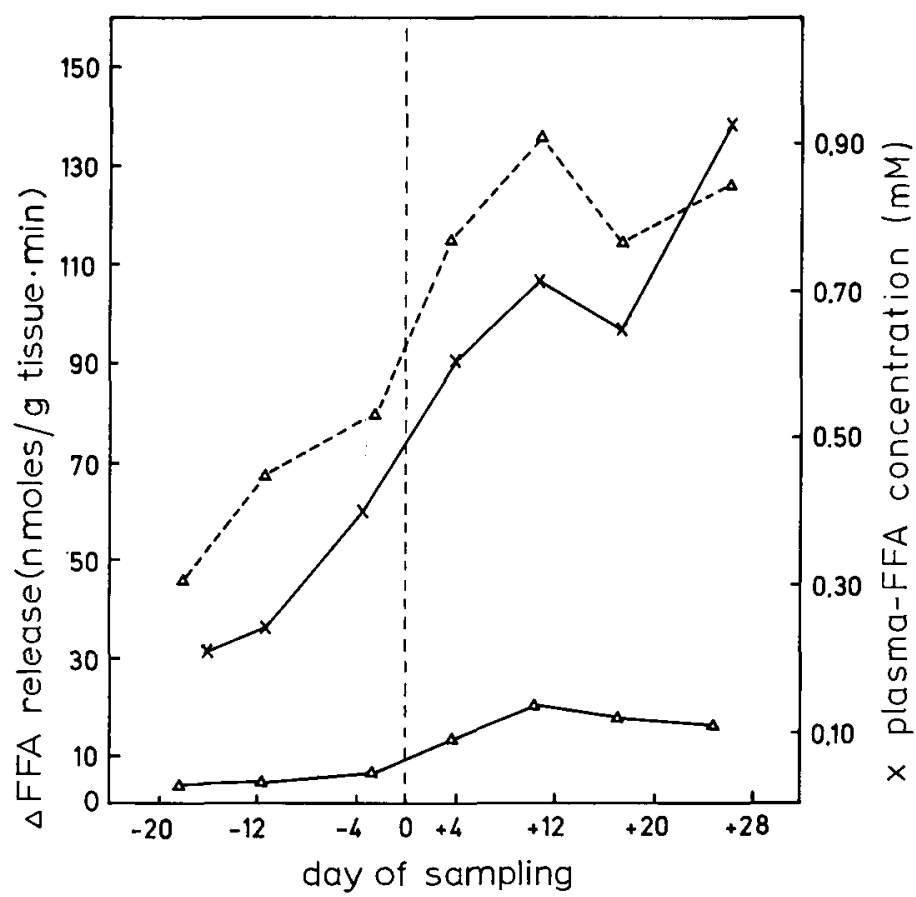

Fig. 5. The release of FFA from adipose tissue in vitro $(\triangle)$ and the FFA concentration in the blood plasma in vivo $(X)$ of 8 cows in the period around parturition. Samples of blood and adipose tissue were taken on the same day from the same animal. The data on FFA release are taken from Fig. $4\left(-=\right.$ without noradrenalin; $\ldots=$ with $2.5 \times 10^{-5} \mathrm{M}$ noradrenalin).

On the other hand, if the donor animal is not in early lactation, glucose may either inhibit or stimulate the production of FFA.

Addition of insulin to the medium did not affect the production and the release of FFA. This lack of an effect of insulin was found both in the absence and in the presence of glucose and/or optimal concentrations of noradrenalin (Tables 1 and 2).

The basal and the noradrenalin-stimulated rates of lipolysis, as measured by the release of glycerol, are not significantly influenced by the addition of glucose (not shown).

\section{Discussion}

Stimulation of lipolysis by noradrenalin

Lipolysis in bovine adipose tissue samples is stimulated manifold by noradrenalin (Fig. 2). This effect has previously been observed in adipose tissue from men, rats, dogs and other mammalian species, but it is absent in adipose tissue from rabbits (Rudman et al., 1963). Adrenalin, which also interacts with adrenergic receptors 
REGULATION OF FAT MOBILIZATION IN COW'S ADIPOSE TISSUE

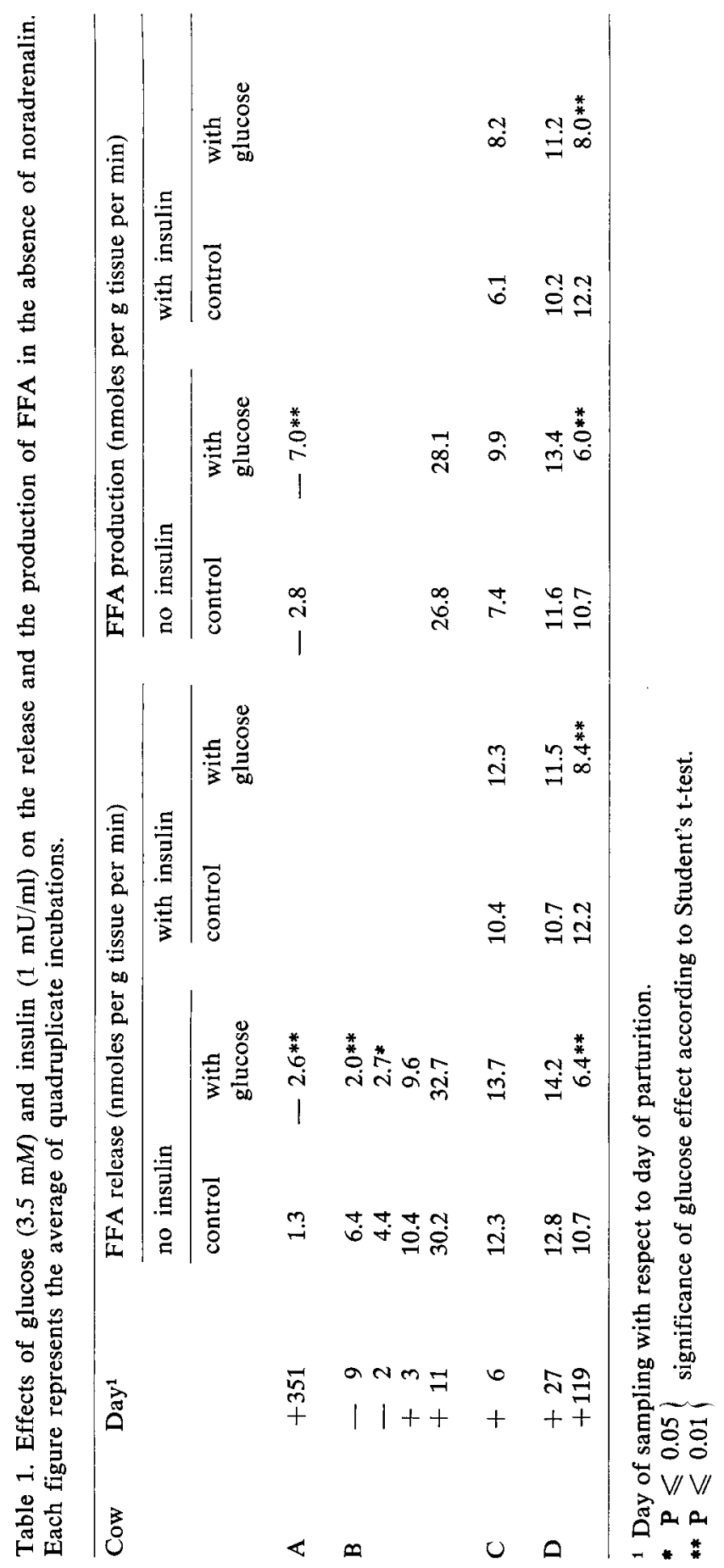

Neth. J. agric. Sci. 25 (1977) 
S. H. M. METZ AND S. G. VAN DEN BERGH

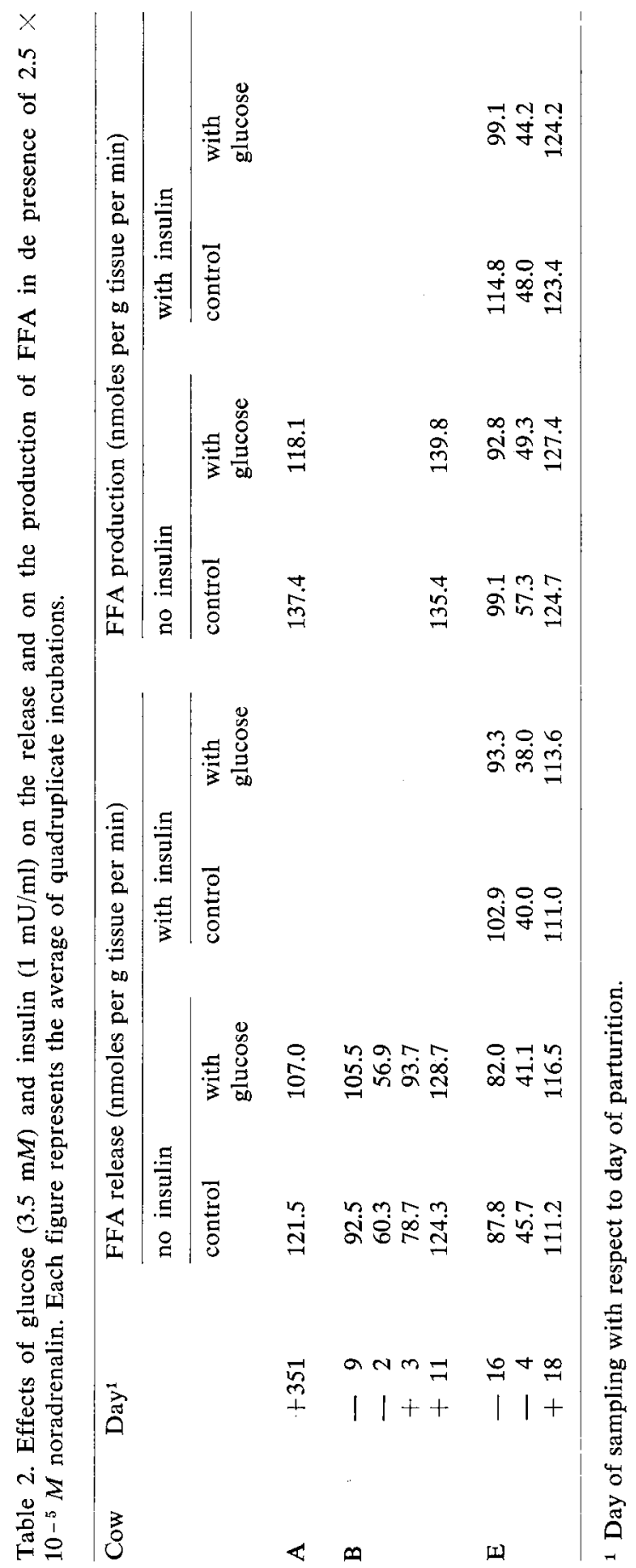


in the fat cell membrane, has also been found to stimulate lipolysis in bovine adipose tissue (Thornton et al., 1972; Yang \& Baldwin, 1973).

The stimulation of lipolysis by catecholamines in rat adipose tissue has been shown to be mediated by cyclic adenosine-3', 5'-monophosphate (cAMP) according to the second messenger concept developed by Sutherland et al. (1965). The ratelimiting enzyme of lipolysis is activated with increasing intracellular levels of cAMP, which is formed from ATP by the action of adenylate cyclase, located in the cell membrane. Catecholamines stimulate the activity of adenylate cyclase. On the other hand, cAMP is continously broken down by phosphodiesterase.

The following arguments lead us to believe that the same mechanism is operating in bovine fat cells:

1. The shape of the dose-effect curves is very similar in bovine and rat adipose tissue;

2. The dibutyryl derivative of cAMP stimulates lipolysis in bovine adipose tissue in vitro (Metz, 1973);

3. Theophylline, an inhibitor of phosphodiesterase, was also found to stimulate lipolysis in adipose tissue of the cow (Metz, 1973).

\section{Lipolysis, FFA release and re-esterification in the period around parturition}

Lipolysis in bovine adipose tissue samples is largely increased after parturition of the donor animal (Fig. 3 and 4). Since lipolysis is measured as the release of glycerol per gram fat, part of the observed increase is undoubtedly a consequence of the increased number of fat cells per gram adipose tissue, due to the reduced fat reserves in a period of negative energy balance. However, the increase in lipolysis is so big that for the largest part it must be caused by an increased lipolytic activity per fat cell.

The mechanism underlying this increased lipolytic activity is not established. Brodie et al. (1969) observed that in fasting rats the increase in lipolysis was accompanied by an increased amount of adenylate cyclase in the adipose tissue. Our results, obtained with adipose tissue in vitro, clearly demonstrate that the increased lipolytic activity after parturition is an intrinsic property of the adipose tissue and is not produced by short-term exogenous factors like altered concentrations of circulating lipolytic hormones.

The increased fat mobilization (Fig. 1, reaction 3) after parturition does not only result from an increased lipolysis (Fig. 1, reaction 1) but also from a diminished re-esterification (Fig. 1, reaction 2). This may be concluded from the increased ratio between FFA release and glycerol release in early lactation (Fig. 3 and 4). This ratio gives an indication of the relative rates of lipolysis and re-esterification. In the absence of re-esterification, FFA and glycerol are produced in a ratio of $3: 1$. With increasing rates of re-esterification the ratio will be lowered.

In order to calculate the rate of re-esterification, it is not enough to measure the rates of release of FFA and glycerol. Changes in the pool size of TAFA should also be known. In a number of experiments (see e.g. Tables 1 and 2) we have, therefore, determined the amount of TAFA before and after the incubation. From the results of these experiments it can be calculated that in adipose tissue samples obtained 
before parturition, in the absence of noradrenalin on the average more than two molecules of FFA re-esterify per mole of triglyceride hydrolysed, whereas after parturition all the reaction products of lipolysis are released from the fat cell, i.e. after parturition no re-esterification of fatty acids occurs.

\section{Effects of noradrenalin before and after parturition}

Before parturition, addition of noradrenalin results in an increased ratio of FFA release and glycerol release; after parturition this ratio is decreased by noradrenalin (Fig. 4). The former effect can be explained by the observations that lipolysis is stimulated by noradrenalin, whereas the rate of re-esterification is not or only slightly affected. The effect of noradrenalin after parturition is more difficult to understand, since both in the absence and in the presence of noradrenalin the rate of re-esterification is negligible. Changes in the ratio of FFA release and glycerol release must, therefore, be brought about by changes in the pool size of TAFA. Such changes could indeed be observed. In the absence of noradrenalin, TAFA always decreased during incubation; in 19 experiments the average decrease of TAFA represented $35 \%$ of the released FFA. In incubations with noradrenalin, TAFA always increased; in 18 experiments the average increase of TAFA amounted to $14 \%$ of the released FFA.

\section{The effect of glucose on fat mobilization}

Except during early lactation, glucose inhibits fat mobilization in vitro. This inhibitory effect of glucose fully agrees with the reciprocal relationship between the concentrations of FFA and glucose in the blood which has been observed in clinically normal and ketotic cows both before and after parturition (Adler \& Wertheimer, 1962; Mulder, 1971a, 1971b; Schultz, 1968; Schwalm \& Schultz, 1976). It is generally accepted that glucose inhibits fat mobilization in vivo and in vitro by stimulating the re-esterification process through the formation of glycerol-3phosphate (Fig. 1) (Patterson, 1964; Bartos et al., 1968). Triglyceride synthesis in bovine adipose tissue occurs mainly via the glycerol-3-phosphate pathway (Benson \& Emery, 1971).

During the first weeks of lactation the inhibitory effect of glucose on fat mobilization is not observed (Table 1). This is in full agreement with the complete disappearance of the re-esterifying activity of the adipose tissue, observed during that period.

If ketotic cows in early lactation are given an intravenous dose of glucose, the FFA concentration in the blood is lowered (Kronfeld, 1965; Erfle et al., 1971). The seeming discrepancy between this effect of glucose in vivo and our results in vitro can be explained if we assume that the effect of glucose, observed in vivo, is not a direct effect on fat mobilization in the adipose tissue. Undoubtedly, many factors are involved in the regulation of the FFA concentration in the plasma and one or more of these factors may be affected by the glucose level in the plasma.

\section{Effect of insulin on fat mobilization}

From the results presented in Tables 1 and 2 it is clear that, at least in our experi- 
mental conditions, insulin has no effect on fat mobilization from bovine adipose tissue in the absence and in the presence of glucose. Insulin stimulates the uptake of glucose in adipose tissue of non-ruminants (Jeanrenaud \& Renold, 1959; Rodbell, 1964) and to a smaller extent in that of ruminants (Khachadurian et al., 1967; Bartos \& Skarda, 1970). Insulin also augments the effects of glucose on re-esterification in adipose tissue of non-ruminants (Jungas \& Ball, 1963; Rodbell, 1964).

The absence of an effect of insulin in our experiments may be partly explained by the observations that the effects of insulin on glucose metabolism in adipose tissue of ruminants decrease with increasing concentrations of glucose (Yang \& Baldwin, 1973) and are rather small unless acetate is present. Since in our experiments the concentration of glucose was fairly high and acetate was never added, it is possible that a considerable effect of insulin could not be expected. It remains unclear, however, why we did not find any effect of insulin at all.

\section{The over-all regulation of fat mobilization in the period around parturition}

From the results presented in this paper it is clear that the increased fat mobilization after parturition of dairy cows results from the combination of an increased lipolytic and a diminished re-esterifying activity in the adipose tissue. These effects may either be brought about by endocrinological changes connected with parturition or they may result from the negative energy balance prevailing during that period. The mechanisms responsible for the changed activities have not been fully established.

An increased lipolytic activity in the adipose tissue of animals with a negative energy balance has frequently been observed (Thornton et al., 1972; Vaughan, 1962; Brodie et al., 1969). Evidence was obtained that in fasting rats the amounts of adenylate cyclase in the adipose tissue was increased (Brodie et al., 1969) but this has not been confirmed for other animal species.

The decreased rate of re-esterification may be related to the decreased activity after parturition of the enzyme system catalysing triglyceride synthesis in the adipose tissue (Baldwin \& Smith, 1971; Shirley et al., 1973). It may also result from a decreased availability of glycerol-3-phosphate for the re-esterification reaction as Baldwin \& Smith (1971) reported a considerable loss of activity of the enzyme glycerol-3-phosphate dehydrogenase in adipose tissue of lactating dairy cows as compared to virgin cows.

We have previously shown that fat mobilization in dairy cows cannot exceed a maximum which is set by the limited binding capacity of serum albumin for FFA (Metz et al., 1973) and by the inhibitory effect on lipolysis of the ketone body 3-hydroxybutyrate (Metz \& van den Bergh, 1972; Metz et al., 1974). It was further shown that an increase in the molar ratio of FFA to serum albumin leads to increased levels of TAFA, resulting in an inhibition of lipolysis.

From the foregoing the following picture arises of the events taking place in the period around parturition. Since the food supply does not cover the energy needs, fat mobilization increases, leading to an increased concentration of FFA in the blood and to an increased FFA to serum albumin ratio. The peripheral utilization of FFA is also increased since milk fat has to be synthesized and since the uptake 
of FFA from the blood in many tissues is directly proportional to the FFA concentration in the blood. The increased FFA to albumin ratio in the plasma limits lipolysis to such an extent that the FFA release from the adipose tissue is in balance with the FFA uptake from the blood by other tissues. The increased supply of fatty acids to the liver, in combination with a low availability of glucose, results in a physiological ketosis and eventually may lead to the clinical symptoms of acetonaemia. In that situation another inhibitor of fat mobilization becomes operative: the increased plasma levels of 3-hydroxybutyrate inhibit further rising of the rate of lipolysis. This will protect the animal from a further intoxication by ketone bodies. It also prevents an over-supply of fatty acids to the peripheral tissues during a period in which huge amounts of ketone bodies are available for oxidative energy supply.

Summarizing it can be said that mechanisms are gradually elucidated which allow the animal on the one hand to cover its increased energy needs in early lactation, and on the other hand protect it against over-mobilization of its energy stores.

\section{Acknowledgments}

The authors thank Mrs W. Klein, Mr R. J. Leer and Mr A. J. van der Molen for skilful technical assistance and $\mathrm{Mr} \mathrm{R}$. Klarenbeek and $\mathrm{Mr} \mathrm{H}$. Noordermeer for their efficient care of the experimental animals. This research was supported in part by the Netherlands Organization for Applied Scientific Research (TNO) and by the Netherlands Foundation for Chemical Research (SON), with financial acid from the Netherlands Organization for the Advancement of Pure Research (ZWO).

\section{References}

Adler, J. H. \& E. Wertheimer, 1962. A reciprocal relationship between blood glucose and plasma free fatty acids (FFA) in dairy cows and its significance for problems of fat metabolism in ruminants. Bull. Res. Coun. Israel 10E: 97-101.

Baldwin, R. L. \& N. E. Smith, 1971. Intermediary aspects and tissue interactions of ruminant fat metabolism. J. Dairy Sci. 54: 583-595.

Bartos, S. \& J. Skarda, 1970. The effect of insulin and acetate on the metabolism of glucose$\mathrm{U}-{ }^{14} \mathrm{C}$ in the adipose tissue of the goat. Physiol. Bohemoslov. 19: 139-144.

Bartos, S., J. Skarda \& F. Dolezel, 1968. The influence of acetate, bicarbonate, glucose, and insulin on the level of NEFA, glucose, and ketone bodies in the blood of goats. Veterinárni Med. 13: 343-350.

Benson, J. D. \& R. S. Emery, 1971. Fatty acid esterification by homogenates of bovine liver and adipose tissue. J. Dairy Sci. 54: 1034-1040.

Brodie, B. B., G. Krishna \& S. Hynie, 1969. On the role of adenyl cyclase in the regulation of lipolysis in fasting. Biochem. Pharmacol. 18: 1129-1134.

Dole, V. P., 1956. A relation between non-esterified fatty acids in plasma and the metabolism of glucose. J. clin. Invest. 35: 150-154.

Eggstein, M. \& F. H. Kreutz, 1966. Eine neue Bestimmung der Neutralfette im Blutserum und Gewebe. Klin. Wochenschr. 44: 262-267.

Erfle, J. D., L. J. Fischer \& F. Sauer, 1971. Effect of infusion of carnitine and glucose on blood glucose, ketones, and free fatty acids of ketotic cows. J. Dairy Sci. 54: 673-680.

Jackson, H. D., A. L. Black \& F. Møller, 1968. Turnover of plasma palmitate in fed and fasted lactating cows. J. Dairy Sci. 51: 1625-1632. 


\section{REGULATION OF FAT MOBILIZATION IN COW'S ADIPOSE TISSUE}

Jeanrenaud, B. \& A. E. Renold, 1959. Studies on rat adipose tissue in vitro. J. biol. Chem. 234: 3082-3087.

Jungas, R. L. \& E. G. Ball, 1963. Studies on the metabolism of adipose tissue. Biochemistry 2: 383-388.

Khachadurian, A. K., M. Kamelian \& B. Adrouni, 1967. Metabolism of sheep adipose tissue in vitro. Am. J. Physiol. 213: 1385-1390.

Kronfeld, D. S., 1965. Plasma non-esterified fatty acid concentrations in the dairy cow: responses to nutritional and hormonal stimuli, and significance in ketosis. Vet. Rec. 77: 30-34.

Metz, S. H. M., 1973. Regulering van de vetmobilisatie in onderhouds vetweefsel van runderen in de periode rond de partus. Thesis (Dutch; summary in English), State University of Utrecht, $93 \mathrm{pp}$.

Metz, S. H. M. \& S. G. van den Bergh, 1972. Effects of volatile fatty acids, ketone bodies, glucose, and insulin on lipolysis in bovine adipose tissue. FEBS Lett. 21: 203-206.

Metz, S. H. M., M. Lopes-Cardozo \& S. G. van den Bergh, 1974. Inhibition of lipolysis in bovine adipose tissue by butyrate and $\beta$-hydroxybutyrate. FEBS Lett. 47: 19-22.

Metz, S. H. M., I. Mulder \& S. G. van den Bergh, 1973. Regulation of lipolysis in bovine adipose tissue by the degree of saturation of plasma albumin with fatty acids. Biochim. biophys. Acta 306: 42-50.

Mulder, I., 1971a. Changes in fatty acid patterns in bovine plasma. Biochem. J. 122: 12 P - 13 P.

Mulder, I., 1971b. Concentration and composition of plasma free fatty acids in cattle at partus. Z. Tierphysiol. Tierernähr. Futtermittelkde 27: 190-192.

Patterson, D. S. P., 1964. The effect of intravenous glucose on depot fat mobilization in the sheep. Res. vet. Sci. 5: 286-293.

Radloff, H. D., L. H. Schultz \& W. G. Hoekstra, 1966. Relationship of plasma free fatty acids to other blood components in ruminants under various physiological conditions. J. Dairy Sci. 49: $179-182$.

Rodbell, M., 1964. Metabolism of isolated fat cells. J. biol. Chem. 239: 375-380.

Rudman, D., S. J. Brown \& M. F. Malkin, 1963. Adipokinetic actions of adrenocorticotropin, thyroid-stimulating hormone, vasopressin, $\alpha$ - and $\beta$-melanocyte-stimulating hormones, Fraction $\mathrm{H}$, epinephrine and norepinephrine in the rabbit, guinea pig, hamster, rat, pig and dog. Endocrinology 72: 527-543.

Schultz, L. H., 1968. Ketosis in dairy cattle. J. Dairy Sci. 51: 1133-1140.

Schwalm, J. W. \& L. H. Schultz, 1976. Relationship of insulin concentration to blood metabolites in the dairy cow. J. Dairy Sci. 59: 255-261.

Shirley, J. E., R. S. Emery, E. M. Convey \& W. D. Oxender, 1973. Enzymic changes in bovine adipose and mammary tissue, serum and mammary tissue hormonal changes with initiation of lactation. J. Dairy Sci. 56: 569-574.

Skarda, J. \& S. Bartos, 1969. The effect of insulin on the utilization of $\left[\mathrm{U}^{14} \mathrm{C}\right]$ glucose and $\left[1-{ }^{14} \mathrm{C}\right]$ acetate by goat adipose tissue in vitro. J. Endocrinol. 44: 115-119.

Sutherland, E. W., I. Oeye \& R. W. Butcher, 1965. The action of epinephrine and the role of the adenyl cyclase system in hormone action. Rec. Progr. Hormone Res. 21: 623-646.

Thornton, J. H., D. C. Beitz \& A. D. McGilliard, 1972. Lipolysis in bovine adipose tissue. J. Anim. Sci. 35: 208.

Vaughan, M., 1962. The production and release of glycerol by adipose tissue incubated in vitro. J. biol. Chem. 237: 3354-3358.

Yang, Y. T. \& R. L. Baldwin, 1973. Preparation and metabolism of isolated fat cells from bovine adipose tissue. J. Dairy Sci. 56: 350-365. 